\title{
How using smart buildings technology can improve indoor environmental quality in educational buildings
}

\author{
Teresa Martinez ${ }^{1}$, Miriam Duarte $^{2}$ and Ana Cristina Garcia-Luna ${ }^{3}$ \\ ${ }^{1}$ Universidad de Monterrey, Av. Ignacio Morones Prieto 4500, Zona Valle Poniente, 66238 San Pedro Garza García, N.L \\ ${ }^{2}$ Universidad de Monterrey, Av. Ignacio Morones Prieto 4500, Zona Valle Poniente, 66238 San Pedro Garza García, N.L \\ ${ }^{3}$ Universidad de Monterrey, Av. Ignacio Morones Prieto 4500, Zona Valle Poniente, 66238 San Pedro Garza García, N.L
}

\begin{abstract}
An educational building must integrate smart building strategies to ensure indoor environmental quality. Thermal, acoustic, visual comfort and indoor air quality are to be considered, otherwise they can develop the sick building syndrome. Smart buildings solve this potential problem by providing a highly efficient living ambience that includes safety, comfort and a good quality of living/learning/working experience, that helps the users achieve their best possible performance. These buildings should integrate advanced technologies such as automated systems and the implementation of architectural skins, well and functional designed spaces and architectural features that act as active bioclimatic solutions. The following is a case study of an architectural project for an elementary and junior high school academic campus in the state of Nuevo León, Mexico that has to deal with the extreme climate conditions of the location, while applying the best alternative and bioclimatic strategies through the implementation of inmotics, a responsive architectural skin, sustainable construction systems and native vegetation. In doing so, a comprehensive environmentally friendly building is created, taking advantage of the surrounding natural conditions, using the latest environmentally oriented systems and technologies. The result is a healthy, safe, and productive space for its users that greatly benefits the teaching-learning process.
\end{abstract}

\footnotetext{
${ }^{1}$ Teresa Martínez: maria.martinezl@udem.edu

${ }^{2}$ Miriam Duarte: miriam.duarte@udem.edu

${ }^{3}$ Ana Cristina Garcia-Luna:anacristina.garcialuna@gmail.com
} 


\section{Introduction}

As Francisco Vargas and Isabel Gallego [1] mention, the different ways in which we interpret environmental conditions have created concepts such as the sick building, in relation to air or interior environmental quality, which seeks to understand the complexity of an indoor microclimate, the possible contaminants in closed environments, and their implications on the health of a building's users. The optimal conditions of the interior environments must generate comfort and well-being for people, promoting a healthy lifestyle at work, school, and in leisure and entertainment areas. Society needs clean, safe and well ventilated spaces that allow them to carry out their daily activities in an adequate way. This is why it is necessary to "achieve a balance between social standards, the use of energy and sustainable development, seeking comfort without polluting and without increasing the consumption of energy sources that degrade the environment" [1].

According to the National Institute for Occupational Safety and Health (2013) [2] Indoor Environmental Quality (IEQ) is the quality of a building's environment regarding the health and wellbeing of its occupants. Many people have noticed that they developed symptoms that cannot be linked to a specific illness or cause, and/or their health and performance are affected when they spend time in some buildings. The particular conditions of these buildings create the emergence of sick building syndrome, observed in many contemporary cities. According to Lili Rodríguez and Jorge Alonzo [3], this syndrome is characterized by a series of discomforts presented by the occupants within the buildings caused by physical, chemical, microbiological, outdoor contaminants and even psychosocial factors. Sick building syndrome is created "when the users of a building experience discomfort in their general health conditions, causing poor comfort, absenteeism and low productivity" [3].

Understanding and applying strategies that generate indoor environmental quality in buildings is of crucial importance, especially in buildings for educational purposes. According to Brink, Loomans, Hobach, and Kort these optimal conditions in the classrooms can contribute to the quality of the teaching-learning process. "Thermal, acoustic, visual and indoor air quality conditions can be of great support for tasks in the classroom of teachers and students" [4].

The buildings that best respond to an environmental design are smart buildings. Their goal is to provide greater efficiency and control in the building's operation, responding to a better quality of life to users inside the buildings [5]. In this way, an active strategy that is used in these buildings is the implementation of architectural skin as an advanced technology that protect the facades from climatic constraints, and regulate an adequate temperature within the buildings. The implementation of a responsive architectural skin, allows the building to respond to ongoing needs through passive and active strategies, that provide a characteristic impact on the performance of buildings. This can be achieved by control strategies and renewable energy systems that improve the energy consumption of the building, its comfort and its functional characteristics for its occupants [6].

This paper explains the problems and effects that contemporary buildings have generated today. The strategies that resolve the environmental conditions of buildings are mentioned through the concepts of intelligent buildings and responsive architecture that helps reduce the energy consumption of the building and allows to maintain an ideal thermal temperature inside the interior spaces. In this paper we seek to highlight the strategies that were established to create optimal indoor environmental conditions in a Montessori school project as a case study. The school is located in San Pedro Garza García, a municipality of the great metropolitan area of the city of Monterrey, Nuevo León, a region of extreme climate conditions in northeast Mexico (semi-arid climate with hot summers, mild winters and little rain year-round), in which technology will be implemented through the incorporation of responsive architectural skin and an artisanal construction system.

\section{The problem with contemporary buildings}

Nowadays there is a trend of building constructions with facades designed entirely of curtain walls. However, these designs present a serious energy problem in cities with a Mediterranean climate: "These glass buildings consume more energy than others because in summer there is a huge demand for air conditioning, while in winter, on the coldest days, there is a loss of heat that has to be compensated" says Antonio Cerrillo [7]. Although this can be used as a strategy to capture light and heat in Nordic areas, these types of buildings become the worst possible construction in Mediterranean cities, from an environmental perspective. The glass generates a good aesthetic since it gives a sense of amplitude and allows the spaces to be well lit. For this reason, this practice is observed a lot in office buildings where large windows are used. However, these buildings generate a large energy expenditure due to its high need for cooling caused by internal heat generation. There are insulating types of glass, but its benefits on energy efficiency are less compared to opaque walls. When designing it is necessary to take into account the external environment and don't rely on air conditioning systems which consumes so much electricity.

As mentioned by Maria Ángela Daza, Diana Ximena Martínez and Paola Andrea Caro [8] "over time, changes in the designs of buildings designed to improve energy efficiency have made homes and 
offices more and more hermetic". Therefore, this type of buildings, which are called "sick buildings", have deficiencies in their indoor generated climate affecting people's health, causing symptoms such as headaches, irritation of the mucous membranes and a feeling of fatigue. Also, technological advances in construction have led to the use of synthetic materials that can easily accumulate pollutants such as volatile compounds, coming from different sources such as heating systems, paints and varnishes in furniture, construction materials or cleaning supplies. Derek Clements-Croome and $\mathrm{Li}$ Bazhan [9] confirm that low indoor air quality and pollution are the factors that contribute the most to the sick building syndrome, in addition to extreme temperature variations, very humid, stale or dry air, that is to say poor quality conditions of an indoor environment. This creates undesirable environments within buildings which lowers the productivity of their occupants.

It is necessary to create building designs that are well integrated to the surrounding environment and climate in order to improve its energy performance. It is important to acknowledge that glass and steel facades have different behaviours depending on the orientation, time and specific climatic conditions of the place. In Mexico, due to its geographic position, if these types of facades are located on the west face of a building, they would receive the highest solar incidence of the day, overheating the entire building. In contrast, if they are located on the north facade, they would be capturing indirect light, which can be used as a lighting strategy. Therefore, the use of glass facades should not be ruled out, but rather learn how, where and when to use them in order to provide a feeling of comfort inside the building.

\section{Opting for an environmental design}

As Randal Thomas [10] mentions, environmental design is not a new concept, but has been applied since the Industrial Revolution when engineers were able to construct buildings in almost any climate around the world. However, to achieve this, high-grade energy has been used to address problems caused by weather conditions and problems resulting from building design. Therefore, it is necessary to reduce the dependency of buildings on fossil fuels, but at the same time achieve the environmental quality that provides comfort to users inside the building. Thomas advises to take advantage of the natural sources of energy, lighting and ventilation, such as the sun and winds. We must stop using the fuel reserves that turn into carbon dioxide when we generate energy with them. In doing so, our activity generates other pollutants released into the environment which have catastrophic effects on the ozone layer. It's necessary to redesign the way we construct buildings to improve the environmental quality, while efficiently reducing the negative impact on the global environment.
According to Rafael Serra and Helena Coch [11], humans are related to the environment since they have energy exchanges of all kinds. The human body seeks to maintain stable internal conditions in a fluctuating environment. This is known as homeostasis. We have specific organs, known as homeostatic mechanisms, that regulate the body's response to environmental loads, such as climatic, lighting, acoustic, and even psychic. It is necessary to make an analysis of the quality of the environment to establish the necessary conditions needed to provide for adequate, sound surroundings. To achieve this, the architecture should adapt accordingly to provide comfort to the users. A good design of habitable environments should integrate environmental parameters, "energetic manifestations, which express the physical and environmental characteristics in a living space, regardless of the use of the space and its occupants", as well as user comfort factors, "conditions outside the environment that influence its appreciation" [11].

\subsection{Thermal comfort}

In addition to what was mentioned by Rafael Serra and Helena Coch [11] one of the general principles of environmental comfort is thermal comfort, which considers thermal parameters of the environment that influence the human body. These are the air temperature, temperature radiation, relative air humidity and air velocity. According to Dima Stouhi [12] one of the first elements to provide thermal comfort is to create an envelope in the building that acts as a filter between the outdoor climate and the indoor environment. This way an interior microclimate is established and stabilized reducing the use of energy-consuming mechanical systems. It is necessary to consider the insulation, solar gain, thermal inertia and air ventilation. Solar gain is the "amount of heat that is generated as the rays are absorbed by the building" [12]. This is controlled by the orientation of the volumes, the wall-window ratio, the level of insulation and the amount of shade of nearby elements. Thermal inertia is "how slowly the temperature of a building reaches that of its surroundings" and is controlled by the materials and type of structure of the building. Likewise, a comprehensive and sound management of the indoors air circulation is necessary so the ventilation efficiently gets rid of the environmental humidity.

\subsection{Acoustic comfort}

According to Lindsey Leardi [13] "acoustic quality depends on how well sound sources are controlled". Unwanted noises are taken into account, whether they are external, internal, caused by impact or emitted by equipment. "The way the human ear perceives sound depends directly on the levels of reverberation and absorption within the building". To achieve acoustic comfort you must first make a good design based on a 
complete site analysis. However, in the end the acoustic performance is in the hands of the finishes. In order to obtain a quality acoustic space, special care must be taken when selecting technologically advanced materials in order to moderate noise levels. Acoustics is a key element in all types of buildings, such as hospitals, theatres, cultural centres, housing, workplaces and, above all, educational buildings.

\subsection{Visual comfort}

José Tomás Franco [14] mentions that this comfort has to do with the correct balance of natural lighting with artificial lighting. Some factors are taken into account for the environmental quality of a space such as the level of flickering, glare, blindness caused by lighting, and uniform distribution of light. "Too much and too little light can cause visual discomfort. Large changes in light levels or sharp contrast (perceived as glare) can cause stress and fatigue" [15]. Natural light should always be prioritized in any design. This is the most comfortable lighting for the human eyes, as they adapt to it naturally. Taking advantage of natural lighting has a positive impact on our health and well-being, increasing our lucidity and productivity during the day, which are necessary factors in an optimal educational setting. It also generates significant energy savings, decreasing the excessive use of artificial light. According to Tomás Franco [14], when designing a new project, the orientation of the building on the site must be carefully considered, in order to use the most and best possible natural light from the correct design of their openings.

\section{$4 \quad$ Smart buildings}

Buildings that pursue environmental quality are called smart buildings. Monteiro, Kowal, Azevedo, Naked, Hammad and Pereira [16] explain that there are different interpretations about these buildings by several researchers. Moten [17] mentions that a smart building is the incorporation of technologies and systems to improve the quality of life of users and the operation of the building. Likewise, Sinopoli [18] explains that an intelligent building is crafted by the use of constructive and automated technological systems that provide safety and comfort in the lifestyle of people. Buckman, Mayfield and Beck also state that "intelligent buildings are constructions that integrate and account for intelligence, operation, control and materials and construction as an entire building system with adaptability, not reactivity, at the core, in order to meet the drivers for building progression: energy and efficiency, longevity, and comfort and satisfaction" [19].

On the other hand, some researchers have focused on the term intelligent buildings, while others have called it smart buildings. However, there is a difference between these two terms [16]. Hoy and Tara
[20] explain the evolution of construction technologies, from primitive to simple, from automated to intelligent to smart buildings. An intelligent building is a simple building whose systems are controlled manually, and an automated building is one whose systems are controlled automatically through the use of sensors that adapt to the needs of the users. On the other hand, smart buildings collect information about how the building is working in real time, using a series of sensors and systems that record the number of people in each of the spaces in any given period of time.

The term smart building has been known since 1980, in an era characterized by telecommunications and computer industry technologies [18]. In addition, this concept has evolved through the development of new technologies that have generated smarter processes to be used in a more flexible, interactive and sustainable way [16].

\subsection{Characteristics of smart buildings}

According to Sinopoli [18], intelligent buildings are characterized by the transmission of technological breakthroughs and the union of building systems, provide the most useful approach to design and implement technological construction systems. Similarly, smart buildings are a critical component for the energy use and sustainability of buildings and the smart grid.

Smart buildings differ from previous generations in their ability to respond, adapt and the flexibility they have in their resources. Thus, adaptability is a fundamental feature of smart buildings. It is the ability to use internal and external information from various sources to prepare the building for specific events before they occur, such as people's perceptions of comfort at different times of the year, changes in the use of the building and the variable characteristics of the occupancy data. Besides adaptability, which is the fundamental piece of an intelligent building, there are four other factors to consider: intelligence, operation, materials and design, and control to define a building as an intelligent system.

\subsection{Positive impact of smart buildings on society and architecture}

Sinopoli [18] mentions that smart buildings use technology to make the building more efficient, create a healthy and productive environment for users, and promote a safe environment with efficient and sustainable energy. According to Ochoa and Guedi [21] the design of smart buildings has created a new expectation about the architectural design solution, which has allowed to harness intelligence using the least amount of energy possible to act on sustainability and environmental design. This can be achieved through the design of passive and active strategies of 
an intelligent building delivering the best comfort to the user with the least possible use of energy. Active strategies are those that adjust to the building according to the internal or external conditions of its environment, achieving comfort and reducing the energy consumption of the building through the most advanced technologies; while passive strategies are those employed by the designer with the aim of responding to the climatic conditions or needs of the environment.

\section{$5 \quad$ Architectural skin}

According to Urquiza [22] one of the ideas that has changed in technological advances is the concept of the facade, an element that is not only identified as the separation that exists between the interior and exterior space of the building, but that also seeks to interact with the environment around it. In this way, the facade becomes the envelope that covers the exterior of a building from the interior, also known as the architectural skin.

In addition, Anwar and $\mathrm{Wu}$ [23] state that the skin in architectural design is a metaphor for the envelopes of buildings, the layer that protects them from the external factors of the environment and helps keep an adequate interior thermal temperature for users. Likewise, the architectural skin aims to establish a dialogue with the user, who can interact through its technological elements or unique characteristics. The design of an architectural skin should have a sustainable objective, considering the establishment of energy and the minimization of energy consumption, using materials and construction details that allows the transfer of energy through the envelope of the building [22].

\subsection{Responsive architecture}

The skin of a traditional building provides stability, regulates air pressure and protects the interior of the building from external environmental factors such as radiation, rain and wind. The architectural skin is an essential component to solve the problems of responsive architecture. Intelligence can be implemented in the architectural skin as a solution for the environmental elements that affect the building [24].

Barozzi, Lienhard, Zanelli and Monticelli mention the following concept: "Responsive: the term refers to a reactive system, i.e. a system that moves and is opposed to the term manipulate, which means that the system is moved and controlled from outside and refers to passive environments" [25].

Besides, responsive architecture is responsible for measuring environmental factors so adapt their shape, color or character accordingly. The goal is to promote the energy efficiency of buildings with the implementation of technologies such as control systems and sensors [24].

\subsection{Responsive architectural skin}

As mentioned by Urquiza [22], at the beginning of the technological era, energy was not directed to preserve the environment, but used to maintain the interior comfort of the building, leading to the consumption of machines and increasing pollution so then, an efficient interaction with nature was sought.

As stated by Faviono, Goia, Perino and Serra [26] the technologies that promote the relationship between the production of renewable energy and the load construction profile are fundamental, since they make use of the responsive elements of buildings. These are elements of buildings that act with a dynamic and active behaviour that improve the exploitation of available natural energy sources. In the technological context, Advanced Integrated Facades (AIF) are a responsive element of buildings that control the energy that flows from the outside to the inside. This facade is an interesting application of advanced solutions for building envelopes, which have been incorporated into research activities and industrial developments. Likewise, the Multifunctional Facade Modules have been developed, architectural skin that present a dynamic behaviour and incorporate different systems that modulate energy and mass flow to reduce energy demand and maximize the quality of the environment. The author mentions some characteristics of the AIF's, such as the ability to transmit, reject and moderate solar radiation, heat losses inside the building and the ability to preserve thermal energy and redirect it.

\section{$6 \quad$ Case study}

\subsection{Project Montessori}

The Montessori project is an educational complex for young students learning through the Montessori teaching method. This education method differs from the traditional model by letting children choose freely what to focus on during their learning experience. According to the Fundación Argentina María Montessori (Maria Montessori Argentinian Foundation) [27], "It is characterized by providing a prepared environment: orderly, aesthetic, simple, real". These prepared or planned environments give children opportunities to engage in work that is interesting to each of them. They are free to focus, discover and investigate on what interests them the most on any given time. The environment in which they work is large, open, and well illuminated spaces, adapted to the size of children and young people that promotes their independence in the exploration and learning process. 
The educational compound is made up of three main areas. First, the administrative area: management offices, admissions, a teacher training center, meeting rooms, and filing areas. Second, academic spaces including classrooms, a library, music, art, dance, and computer rooms, as well as a cafeteria, theatre, and gym. Finally, the sports field that includes basketball, soccer, volleyball courts, as well as a recreation space for parents.

The objective of this project is to develop an architectural proposal that introduces an innovative solution to fulfil the needs of a Montessori method based school, adapted to the present conditions and those of the future generations for a basic education campus (pre-elementary, elementary and junior highschool) in the metropolitan area of Monterrey, Nuevo León, Mexico. School should be an ideal space for children to learn and develop their cognitive, motor, and verbal skills, as well as an interest in discovering the world around them.

Our project is developed north of the municipality of San Pedro Garza García in Nuevo León, Mexico. According to data from INEGI (Instituto Nacional de Estadísticas, Geografía e Informática de Mexico - National Institute of Statistics, Geography, and Informatics), [28] 68\% of the territory of Nuevo León has an extreme dry and semi-dry climate, especially towards the Sierra Madre Occidental. This project would be located on the slopes of this mountain chain, bordering with the Santa Catarina River which has a basin area of $1,804.7 \mathrm{~km} 2$ and is located more than $2,200 \mathrm{~m}$ above sea level. According to Comisión Nacional del Agua (the National Water Commision)[29] the riverbed is mostly dry as Servicios de Agua y Drenaje de Monterrey (Monterrey Water and Sewage Services) have located around 30 water wells with depths between 80 and 114 meters. The annual temperature of Nuevo León ranges between $9^{\circ} \mathrm{C}$ and $34^{\circ} \mathrm{C}$ in average and rainfall is, in general, quite scarce, although some regions can register an annual rainfall greater than $800 \mathrm{~mm}$. The general annual average of the State oscillates between 300 and $600 \mathrm{~mm}$ with rains occurring mainly during the summer, making it a very humid place. According to data from the Secretaría de Desarrollo Sustentable de Nuevo León (Secretary of Sustainable Development of Nuevo León) [30] the average relative humidity of the San Pedro Garza García area is $59.9 \%$, the ideal being between $40 \%$ and $60 \%$; wind is also considered an important factor in the variation of the temperature. Within the metropolitan area, this specific location reports one of the highest wind speeds, rising above 22 $\mathrm{km} / \mathrm{h}$ from the east and southeast. According to the Red de Monitoreo del Gobierno del Estado de Nuevo León (Monitoring Network of the Government of the State of Nuevo Leon) [31], the property is located within an area that has an acceptable regular air and health index of $65 \mathrm{ugr} / \mathrm{m} 3$ as a percentage of PM10 (particles in the environment of less than 10 micrometers), the ideal being less than $50 \mathrm{ugr} / \mathrm{m} 3$.

\subsection{Strategies to generate indoor environmental quality}

Considering the extreme climatic conditions of the area, it was sought to implement solar capture strategies for heat and lighting, the use of winds, the catchment of rainwater, to protect the building from the environment, generating comfort and indoor environmental quality.

\subsubsection{Rammed earth construction system}

To build this project, it was decided to apply rammed earth, a construction system where the transformation of the soil and the building are part of the same process. This consists of filling a formwork with layers of soil, compacting each one of them with a tamper, until the desired height of the wall is reached. The formwork is made up of two parallel wooden planks joined by a crossbar with a considerable thickness of variable width between 50 and $70 \mathrm{~cm}$. As Byron Febres explains [32], the rammed earth technique has been used for millennia in regions such as India, China, Egypt, Bolivia and Peru. It is known that this building technique was used as early as $1700 \mathrm{AC}$ by the Chinese to create fortifications, palaces and even in the construction of some sections of the Great Wall. Since then, it had been used by many civilizations. This building method increased its popularity and mass application in the 19th century, when French builders developed manuals, that were translated into different languages, explaining this construction process, thus expanding this technique around the world.

The rammed earth is a method that requires highly specialized labour and it is not encourage selfconstruction. However, rammed earth is an excellent material. According to the engineer Byron Febres [32], it transpires, like clay, is hygroscopic, meaning it can absorb moisture from the environment, and has the ability to expand. It can store cold and heat, making it a great insulator and has low thermal expansion, as well as a great acoustic behaviour, due to its thicknesses. Also, when the material is hardened, it has good resistance against wear and tear. These characteristics make this technique an excellent bioclimatic strategy that helps to maintain a stable temperature inside the building throughout the year, regardless of intense cold or extreme heat such as that experienced in Nuevo León. In addition, the rammed earth wall provides a characteristic aesthetic that generates in users a sense of appreciation towards the materials of the earth and the natural environment. It is used on exterior walls of the buildings and the facades include large windows to take advantage of natural light. As it is not possible to have these glass facades over all of the sides of each building, they were implemented only on the main facade of each one, thussolving the lighting issue. 


\subsubsection{Native Vegetation}

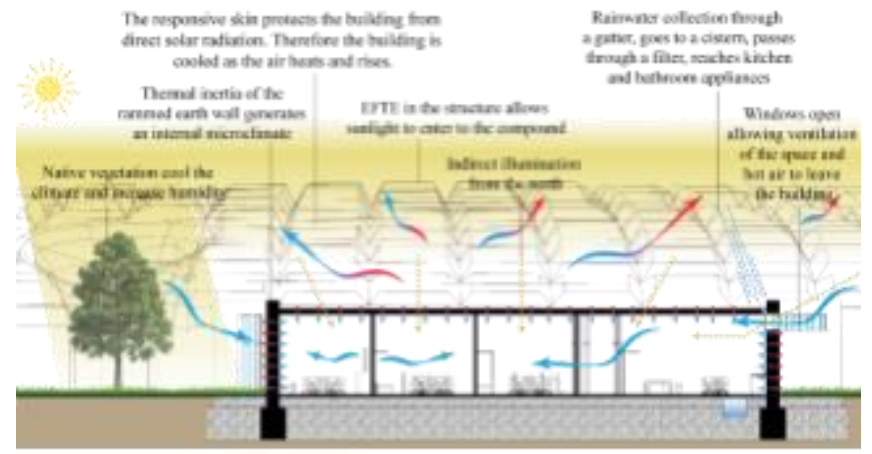

Nis L. Biodinuse diagrame of a tudifine

To counteract the solar incidence on the most vulnerable facades, native vegetation is used as protection. Special attention is paid to the green areas of the site, due to the characteristics of its behaviour with the climate. Green areas cool down spaces and increase the humidity of the environment in the surroundings. In this way, the predominant presence of trees and shrubs of different and varied dimensions will lower the temperature of the place generating a microclimate. The vegetation is used as a passive cooling strategy since it allows to manipulate the winds taking advantage of the volumetric shape of the complex.

In the same way, Zupancic, Westmacott and Buthius [33] mention this strategy has the ability to filter pollutants in the air and mitigate the temperature of both the air and the soil, providing some health benefits for users. They benefit directly from the use of vegetation due to the shade it produces, as well as indirectly thanks to the phenomenon of evapotranspiration: "the water is returned from the earth's surface to the atmosphere in form of water vapor "[34]. According to the Plan Municipal de Desarrollo Urbano (Municipal Plan of Urban Development) [35], the city of San Pedro Garza García is in close proximity to the natural areas of the Sierra Madre Oriental and Cerro de Las Mitras (Mitras Mountain). The project seeks to highlight the privileged location of the property and the high quality of native trees, since the area where it is built preserves its original vegetation.

With the help of these strategies, the goal is to generate a microclimate that provides environmental quality within the complex. The microclimate defines the set of climatic conditions typical of a geographic point or reduced area and represents a local modification of the general climate of the region due to the influence of different ecological factors [36]. To create it, in addition to the use of mud (rammed earth technique) and the vast native trees and vegetation within the property, a responsive architectural skin is used.

\subsubsection{Responsive Skin}

The responsive skin that protects the building is made up of a self-supporting structure in the shape of two intersecting octagonal domes of approximately 150 meters in diameter, which encompass the entire project buildings. This structure is made up of modules in the form of trapezoidal prisms, and because these are adapted to the curved shape of the dome, they have very varied measurements from $2.5 \mathrm{~m} \mathrm{x} 4 \mathrm{~m}$ to $0.9 \mathrm{~m} \mathrm{x}$ $3.25 \mathrm{~m}$. These modules were generated parametrically, so they are more open in their upper part, depending on the entry of the prevailing winds. That is why the largest modules are located in the southeast part of the structure.

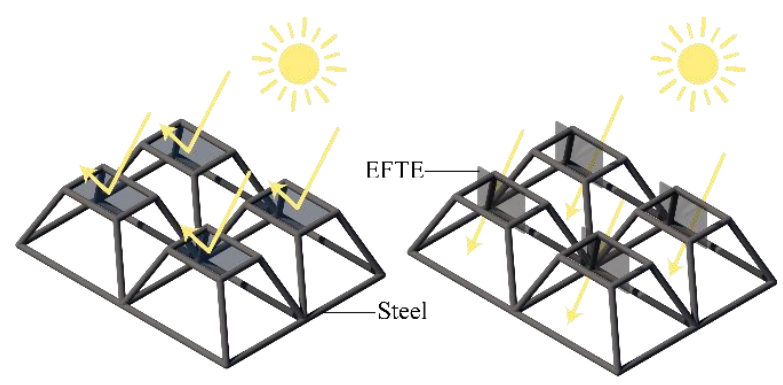

Fig. 2. Modules structure

A responsive skin is made up of smart materials that respond to changing environmental conditions. In the upper part of each module, an EFTE (ethylene tetrafluoroethylene) element, which reacts to temperature variations by rotating, is used allowing or preventing the passage of ultraviolet rays through the structure. This material has been increasingly used in architecture due to its bioclimatic qualities. It is a film made of a heat-resistant polymer that has a great ability to regulate the environmental conditions inside buildings, according to Patrick Lynch [37]. Besides, it has a low coefficient of friction that prevents dust and dirt from sticking to its surface, thus dropping the maintenance requirements. It provides a high light transmission letting in natural sunlight, allowing visibility through the structure. And it also has a high chemical resistance, stable to changes in temperature and ultraviolet rays. In short, it is a robust thermal insulator, a great solar protection for the project.

Likewise, Urquiza [22] mentions that the responsive architectural skin behaves as an active bioclimatic strategy that acts according to external environmental circumstances to maintain an ideal thermal condition in the interior spaces of the building, without using an additional energy system, such as heating or the air conditioning. The author explains that there are two main factors that influence human bioclimatic comfort: air temperature and relative humidity. These factors can be modified by three parameters: air flow velocity, solar radiation, and evaporation. These parameters are used in the project by controlling the speed of the air flow through natural cross ventilation, which generates a cool environment in each of the buildings. Solar radiation is controlled by regulating the temperature throughout the buildings with the help of the architectural skin provided by the modules and by offsetting the solar incidence of the 
most vulnerable facades. Finally, the integration of native vegetation in the project helps to deal with the need for humid air to control evaporation.

\subsubsection{Inmotics}

Smart buildings have a wide variety of automated and efficient technologies that reduce energy consumption, improve the quality of life of users and record necessary information through different sensors and control systems. One of these technologies is inmotics. Antonio Núñez [38] mentions that the inmotics "encompasses the integration of the facilities of tertiary sector buildings", like hotels, hospitals, office buildings, universities, or large areas, such as parking lots and sports fields. Inmotics, as building automation, is an active control system which allows the building to function intelligently, just as home automation does with homes. "Its systems allow an efficient management of energy consumption, security, accessibility and comfort of the building" [39].

The project has automated systems that respond efficiently to the user needs. It has a hybrid ventilation system that makes use of natural and mechanical ventilation. The automated ventilation system detects when spaces need ventilation and can also be programmed to detect levels of contaminants, such as CO2. This mechanical ventilation system is used on top of natural ventilation, as it is not a constant and steady steam [40]. Energy savers elements as dimmers, motion sensors and controlled systems are also added to help reduce energy consumption through lighting, heating, and cooling in each building. To enhance the interior comfort of the building, systems are used to regulate the temperature, the intensity of the light using the most of natural light with the help of automated curtains and blinds, as well as sound and video systems through applications on cell phones and screens. Accessibility and security features are built into automated systems allocating customized buzzers, so users can communicate internally or externally. Access control is also applied by means of high security systems that authenticates the identity of the visitor, as well as the use of alarms and surveillance cameras to supervise the safety of the smallest children. Likewise, it incorporates a fire protection system that not only activates the alarms in the event of a gas leak, but also shuts down the power to prevent electrical sparks from triggering fires and opens the windows automatically to ventilate the affected spaces.

\section{Conclusion}

The analyzed bibliography for this approach confirms the importance of having an optimal indoor environmental quality in an educational building and rely in the fact that it has a positive impact on user productivity. According to Jungsoo Kim and Richard de Dear [41], temperature, noise volume, size of spaces, visual perception, colors, and textures are some basic factors that need to stay at acceptable levels as they greatly influence the wellbeing of people within a building. Likewise, air quality, the amount of light and visual comfort are some secondary factors that proportionally decrease or increase the level of user satisfaction. This is essential in educational buildings, since according to Montiel Vaquer [42] there is a correlation between the architectural environment and children or young people who live, develop, or interact within it. A quality environment can help meet the objectives of an educational project. An educational project should not be conceptualized only on the protection issue, it must be designed thinking on how its future users will optimally develop. More affective and sensitive constructions are needed to the specific needs of children and young people. According to Mora [43] mental performance deteriorates when people do not feel comfortable in specific spaces or if the conditions of the place are not the most suitable to attain a specific mental activity.

The implementation of the rammed earth wall technique is ideal in the construction of educational buildings in this region of Nuevo León in northeastern Mexico, due to its thermal and acoustic characteristics. It transforms the educational sites into optimal spaces where children and young people experience a quality and fulfilling learning process. The usage of native trees and vegetation around the property, along with the artisanal construction system of the rammed earth, generate a sense of belonging in the users, making them feel connected with nature. This feeling of connection is important to awaken the interest and respect for their environment and will encourage them to take care and protect it, just as the space itself does with them.

Likewise, the responsive architectural skin serves as an environmentally oriented technology, by using efficiently climatic elements such as wind and sun rays to regulate the climatic characteristics inside the premises, creating an ideal microclimate for users. It works as an active bioclimatic strategy that adapts to the climatic conditions of the site and obtains positive impacts on the interior and exterior spaces of the project. The architectural skin is large enough to protect the buildings and is fully customized, allowing convenient levels of light and ventilation to flow through the building contributing to an environmental quality needed for the educational complex.

The building incorporates other technological alternatives like inmotics, which adapts to the current rhythm of life of children, teachers and collaborators in the different spaces of the project, as well as the implementation of technological advances that contribute to make it a more human, flexible and multifunctional project. In addition to providing energy efficiency, comfort and environmental benefits, the project has a strong social impact, as mentioned by 
Juan Carlos Sarasúa [44]. People with disabilities and the elderly are provided with greater autonomy, empowering them to have control of the facilities through a remote control system adapted to their specific needs.

The combination of environmental design strategies implemented in this project, respond to the current problems of the site, provide better comfort to users, reduce energy consumption, and take advantage of the natural factors of the environment, such as ventilation, natural lighting and sunlight. This project becomes a meeting point between technology, education, architecture, and nature.
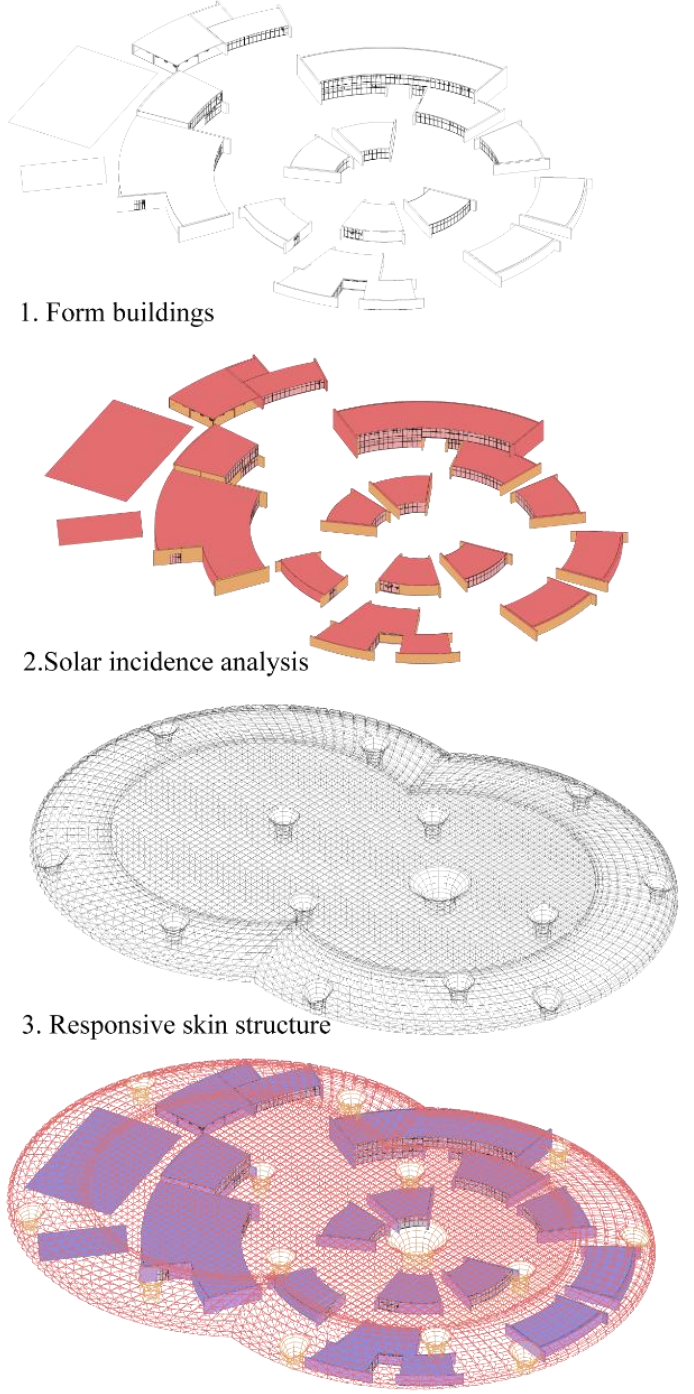

4. Solar incidence over responsive skin protecting the buildings

Fig. 3. Structure performance

\section{References}

1. F. Vargas, I. Gallego, Rev. Esp. Salud Pública, Calidad Ambiental Interior: Bienestar, Confort y Salud, 79, 243-251, (2005)

2. NIOSH, Indoor Environmental Quality, https://www.cdc.gov/niosh/topics/indoorenv/defau lt.html\#: : :text=Overview,air\%20quality\%2C\%20a nd\%20damp\%20conditions (2013)
3. L. Rodríguez, J. Alonzo, Ingeniería, Efecto de los factores ambientales, laborales y psicosociales, en el síndrome del edificio enfermo, 8, 1-8, (2004)

4. H. Brink, M. Loomans, M. Hobach, H. Kort, EFMIC2020, The influence of indoor environmental quality on perceived quality of learning in classrooms for higher education, (2020)

5. R. Abrantes. QQML. Information Systems: Applications in Smarts Cities, Smart Buildings and Smart Life, 8, 3.323 - 335, (2019)

6. E. Taveres-Cachat, S. Grynning, J. Thomsen, S. Selkowitz. Elsevier. Responsive building envelope concepts in zero emission neighborhoods and smart cities - A roadman to implementation, 149, 446 - 457, (2018)

7. A. Cerrillo, La Vanguardia, Edificios de cristal: nuevos focos del cambio climático, https://www.lavanguardia.com/natural/cambio-cli matico/20190503/461989026988/edificios-de-crist al-invernaderos-pich-aguilera-jordi-cipriano-marg arita-de-luxan.html (2019)

8. M. Daza, D. Martínez, P. Caro, Biociencias, Contaminación microbiológica del aire al interior y el síndrome del edificio enfermo, 10, 37-50 (2015)

9. D. Clements-Croome, L. Baizhan, PHB, Productivity and Indoor Environment, 1, 629-634, (2000)

10. Randall Thomas, Environmental Design (Taylor \& Francis Group, 2006)

11. R. Serra, H. Coch, Arquitectura y energía natural (Edicions UPC, 1995)

12. D. Stouhi, ArchDaily, Cómo diseñar para un óptimo confort térmico (y por qué es importante), https://www.archdaily.mx/mx/910532/como-disen ar-para-un-optimo-confort-termico-y-por-que-es-i mportante (2019)

13. Lindsey Leardi, Archdaily, Principios básicos de acústica: los arquitectos no deberían dejar todo a los especialistas, https://www.archdaily.mx/mx/911307/principios-b asicos-de-acustica-los-arquitectos-no-deberian-dej ar-todo-a-los-especialistas (2019)

14. J. T. Franco, Archdaily, ¿Qué es el confort visual y cómo aplicarlo en la arquitectura?, https://www.archdaily.mx/mx/911593/consejos-uti les-para-garantizar-el-confort-visual-en-el-disenoarquitectonico (2019)

15. Saint-Gobain Building Science team, Indoor environment and well-being, (2016)

16. M. Monteiro Froute, C. Kowal, A. Azevedo, A. Naked, A. Hammad, C. Pereira. MDPI. Smart Buildings: Systems and Drivers, 10, 153, (2020)

17. B. Moten, Smart Buildings: Leadership, Data and Accountability (FMJ, 2020)

18. J. Sinopoli, Smart Building Systems for Architects, Owners, and builders (Elsevier, 2010) 
19. A. H. Buckman, M. Mayfield, S. B. M. Beck. SASBE. What is a Smart Building? 3,2. 92 - 109, (2014)

20. M. B. Hoy, T. J. Brigham. Routledge, Smart buildings: An Introduction to the Library of the Future, 35, 3. 326 - 331, (2016)

21. C. E. Ochoa, I. Guedi. Elsevier. Strategic decision - making for intelligent buildings: comparative impact of passive design strategies and active features in a hot climate, 43, 1829 - 1839, (2008)

22. R. Urquiza, International Journal of Architectural Computing, Parametric Performative Systems: Designing a Bioclimatic Responsive Skin, 8, 279 300, (2010)

23. J. Wu, S. Anwa, Common Ground, Ruga Architectural Skin (RAS) Toward Building Smart Self - folding Topology, 7, 17 - 30, (2016)

24. S. Verma, P. Devadaas, Adaptative skins: Responsive building skin systems based on tensegrity principles, 155 - 170, (2013)

25. M. Barozzi, J. Lienhard, A. Zanelli, C. Monticelli. Elsevier, The sustainability of adaptive envelopes: developments of kinetic architecture, 155, 275 - 284, (2016)

26. F. Favoino, F. Goia, M. Perino, V. Serra. Elseiver, Experimental analysis of the energy performance of an active, responsive and solar (actress) facade module, 133, 226 - 24, (2016)

27. Fundación Argentina María Montessori, El método Montessori, https://www.fundacionmontessori.org/metodo-mo ntessori.htm (2018)

28. INEGI, Conociendo Nuevo León, 1-36, (2013)

29. CONAGUA, Diario Oficial de la Federación, Actualización de la disponibilidad media anual de agua en el acuífero Campo Buenos Aires (1907), Estado de Nuevo León, 1-18 (2018)

30. Secretaría del Desarrollo Sustentable Nuevo León, SIMA, Reporte del estado de la calidad del aire en el área metropolitana de Monterrey, 1-23 (2015)

31. Red de Monitoreo del Gobierno del Estado de Nuevo León, Mapa de promedio móvil en el área metropolitana de Monterrey, http://aire.nl.gob.mx/map_calidad.html (2020)

32. B. Ferbes, CUJAE, Vivienda de Interés Social de dos Plantas en base a Tapial como una alternativa para el Barrio "Mirador" Situada en la parroquia de Malacatos, Ciudad de Loja: Materiales y Estructuras, 1-95 (2010)

33. T. Zupancic, C. Westmacott, \& M. Bulthuis, David Suzuki Foundation, The impact of green space on heat and air pollution in urban communities: A metanarrative systematic review, 1-68 (2015)

34. T. Tarin, E.A. Yépez, J. Garatuza-Payan, C. Watts, J. Rodríguez, E. Vivoni, L. Mendez-Barroso, Tecnología y Ciencias del Agua, Partición de 1 a evapotranspiración usando isótopos estables en estudios ecohidrológicos, 5, 97-114 (2014)
35. Implan San Pedro Garza García, Plan de Desarrollo Urbano Municipal 2030, (2014)

36. B. Barnes, D. Zak, S. Denton, S. Spurr, Forest ecology (Wiley, 1998)

37. P. Lynch, Archdaily, ¿Por qué el EFTE se ha convertido en el polímero favorito de la arquitectura?

https://www.archdaily.mx/mx/914506/por-que-elefte-se-ha-convertido-en-el-polimero-favorito-de-1 a-arquitectura (2019)

38. Antonio Núñez, Ediciones Experiencia, Domótica e Inmótica KNX: Guía práctica para el instalador. (2011)

39. Materials. Archdaily. ¿Qué es la domótica en la arquitectura?,

https://www.archdaily.mx/mx/903363/que-es-la-d omotica-y-cual-es-el-impacto-de-la-automatizacio n-en-la-arquitectura (2018)

40. M. Schires, Archdaily, La importancia de diseñar contemplando una buena calidad de aire interior, https://www.archdaily.mx/mx/916475/la-importan cia-de-disenar-contemplando-una-buena-calidad-d e-aire-interior (2019)

41. J. Kim, R. de Dear, Building and Environment, Nonlinear relationships between individual IEQ factors and overall workspace satisfaction, 49, 3340 (2012)

42. I. Montiel, Revista Doctorado UMH, Neuroarquitectura en educación. Una aproximación al estado de la cuestión, 3 (2) (2017)

43. Mora, F., Alianza Editorial, Neuroeducación: sólo se puede aprender aquello que se ama, (2017)

44. C. Sarasúa, Revista Módulo, Domótica. Un factor importante para la arquitectura sostenible, $\mathbf{1}$, 267-277, (2001) 